\title{
Pertumbuhan Bibit Cengkeh (Syzygium aromaticum (L.) Merr \& Perr.) Zanzibar pada Berbagai Taraf Dosis Pupuk Majemuk NPK (15 : 15 : 15) dan Konsentrasi Auksin 2.4-D
}

\section{Growth of Clove Var. Zanzibar Seedlings (Syzygium aromaticum L. Merr \& Perr) at Various Doses of NPK Compound Fertilizer and Auxin 2.4-D Concentration}

\author{
Wahyu Angga Direja dan Ade Wachjar*
}

\author{
Departemen Agronomi dan Hortikultura, Fakultas Pertanian, Institut Pertanian Bogor \\ (Bogor Agricultural University), Jl. Meranti, Kampus IPB Darmaga, Bogor 16680, Indonesia \\ Telp. \& Faks.62-251-8629353 e-mail agrohort@apps.ipb.ac.id \\ *Penulis Korespondensi : wachjarade@yahoo.co.id \\ Disetujui : 1 Oktober 2018 / Published Online 06 Mei 2019
}

\begin{abstract}
This study aims to find a combination of doses of NPK fertilizer and concentration of Auksin 2.4D optimum for growth of clove seedlings. The experiment was conducted at IPB Experimental Garden, Cikabayan, Dramaga, Bogor, from October 2016 until June 2017. The experiment design was Randomized Complete Block Design (RCBD). The first treatment was NPK compound fertilizer (15:15:15) with four dosage levels ie $5 \mathrm{~g}$ per seed (P0), $10 \mathrm{~g}$ per seed (P1), $15 \mathrm{~g}$ per seed (P2) and $20 \mathrm{~g}$ per seed (P3). The second treatment was Hydracilla with 4 dosages ie $0 \mathrm{ml}$ per liter of water (Z0), $0.5 \mathrm{ml}$ per liter of water (Z1), $1 \mathrm{ml} \mathrm{per}$ liter of water (Z2) and $1.5 \mathrm{ml}$ per liter of water (Z3). The results showed that NPK compound fertilizers tend to have a significant effect ( $F$ test on $\alpha 0.1$ ) to root weight ratio, but did not give any significant effect on other variables. The concentration of auxin gave a significant effect on plant height at 1 MAT (Month after Treatment) and tended to have a significant effect ( $F$ test at $\alpha 0.1$ ) on the height of seedlings at 4 and 5 MAT, but did not give any significant effect on other variables. There is a real effect of NPK and auxin fertilizer interaction on root length and tends to have real effect ( $F$ test at a 0.1) on Wet Heading Edge. No optimum dose was found in NPK compound fertilizer for growth of clove seeds, but there was an optimum concentration in a $2.4 \mathrm{D}$ auxin that was $1.58 \mathrm{ml}$ per liter of water in the height growth of clove seedlings.
\end{abstract}

Keywords: auksin 2.4-D, clove seedlings, NPK fertilizer

\begin{abstract}
ABSTRAK
Penelitian ini bertujuan untuk mencari kombinasi dosis pupuk NPK dan konsentrasi Auksin 2.4D yang optimum untuk pertumbuhan bibit cengkih. Penelitian dilakukan di Kebun Percobaan IPB, Cikabayan, Dramaga, Bogor, mulai bulan Oktober 2016 sampai Juni 2017. Rancangan percobaan yang digunakan adalah Rancangan Acak Kelompok (RAK). Perlakuan pertama adalah pemberian pupuk majemuk NPK (15:15:15) dengan empat taraf dosis yaitu $5 \mathrm{~g}$ per bibit (P0), $10 \mathrm{~g}$ per bibit (P1), $15 \mathrm{~g}$ per bibit (P2) dan 20 g per bibit (P3). Perlakuan kedua adalah pemberian Hydrasil dengan 4 taraf dosis yaitu $0 \mathrm{ml}$ per liter air (Z0), $0.5 \mathrm{ml}$ per liter air (Z1), $1 \mathrm{ml}$ per liter air (Z2) dan $1.5 \mathrm{ml}$ per liter air (Z3). Hasil penelitian menunjukkan pemberian Pupuk majemuk NPK cenderung berpengaruh nyata (Uji F pada $\alpha 0.1$ ) terhadap rasio bobot akar, tetapi tidak memberikan pengaruh nyata pada peubah lainnya. Konsentrasi auksin memberikan pengaruh nyata terhadap tinggi tanaman pada 1 BST (Bulan Sesudah Perlakuan) dan cenderung berpengaruh nyata (Uji F pada $\alpha 0.1$ ) terhadap tinggi bibit pada 4 dan 5 BSP, tetapi tidak memberikan pengaruh nyata terhadap peubah lainnya. Terdapat pengaruh nyata interaksi pupuk NPK dan auksin terhadap panjang akar dan cenderung berpengaruh nyata (Uji F pada a 0.1) terhadap Bobot Basah Tajuk. Tidak ditemukannya dosis optimum pada pupuk majemuk NPK untuk pertumbuhan bibit cengkih, tetapi terdapat konsentrasi optimum dalam pemberian auksin 2.4D yaitu sebesar $1.58 \mathrm{ml}$ per liter air dalam pertumbuhan tinggi bibit cengkih.
\end{abstract}

Kata kunci: auksin 2.4-D, bibit cengkih, pupuk NPK 


\section{PENDAHULUAN}

Tanaman cengkih (Syzygium aromaticum L. Merr \& Perr.) termasuk dalam famili Myrtaceae dan merupakan tanaman asli Indonesia yang berasal dari Kepulauan Maluku (Indrawanto dan Ferry 2007). Cengkih merupakan tanaman rempah yang sangat penting dan dibutuhkan. Pada mulanya, cengkih hanya dipergunakan untuk obatobatan, tetapi dalam perkembangannya pemanfaatan cengkih menjadi lebih luas, yaitu sebagai rempah-rempah, bahan baku industri farmasi, kosmetika, parfum, sumber eugenol dan yang terbesar sebagai bahan baku industri rokok kretek (Disbun Jabar, 2014).

Tanaman cengkih merupakan salah satu komoditas perkebunan yang mempunyai nilai ekonomi tinggi. Rumagit (2007) mengemukakan bahwa cengkih merupakan komoditas yang strategis bagi perekonomian nasional. Strategis sebab Indonesia adalah negara produsen, konsumen, dan pengimpor cengkih terbesar di dunia dan berperan langsung dalam penyerapan tenaga kerja.

Luas areal tanaman cengkih mengalami peningkatan dari 493888 ha pada tahun 2012 menjadi 542281 ha pada tahun 2016. Produksi cengkih menurun dari 99890 ton pada tahun 2012 menjadi 139522 ton pada tahun 2016. Volume ekspor cengkih terlihat meningkat dari 5941 ton tahun 2012 menjadi 8477 ton pada tahun 2016, pada tahun yang sama terjadi penurunan volume impor, yaitu sebesar 7164 ton pada tahun 2012 menjadi 6571 ton pada tahun 2016 (Ditjenbun, 2017). Impor cengkih dilakukan untuk memenuhi kebutuhan dalam negeri bedasarkan produksi tanaman cengkih yang belum mencukupi. Untuk memenuhi kebutuhan cengkih dalam negeri perlu upaya meningkatkan produksi, salah satu upaya yang dapat dilakukan adalah peremajaan. Peremajaan diperlukan untuk peningkatan produktivitas tanaman cengkih sudah tua dan rusak yang disebabkan serangan hama dan penyakit, kurang pemeliharaan dan belum menggunakan bibit unggul (Ditjenbun, 2013).

Untuk melaksanakan peremajaan dan agar peremajaan menghasilkan produktivitas, kualitas dan produksi cengkih yang baik diperlukan suatu upaya, baik mulai pra tanam hingga pascapanen, salah satunya adalah dengan meningkatkan kualitas bibit. Menurut Wahyuno dan Martini (2015) kriteria bibit yang siap tanam adalah sehat, tinggi bibit $60 \mathrm{~cm}$ (1 tahun) atau $90 \mathrm{~cm}$ (2 tahun), memiliki $6-7$ cabang, daun berwarna hijau tua, mempunyai batang tunggal, mempunyai akar tunggang yang lurus dengan panjang akar sekitar $40-45 \mathrm{~cm}$ dan $30-35 \mathrm{~cm}$ akar cabang serta bibit dipindahkan tidak lebih dari 1 tahun bila bibit ditanam di polybag. Penelitian tentang pembibitan cengkih untuk mendapatkan bibit yang berkualitas belum banyak dilakukan. Peningkatan produksi cengkih yang maksimal, baik di tingkat petani, perusahaan swasta maupun tingkat pemerintah dapat dilaksanakan dengan menggunakan bibit varietas cengkih unggul. Oleh karena itu penelitian tentang pembibitan cengkih perlu dilakukan.

Untuk melaksanakan peremajaan dan agat peremajaan menghasilkan produktivitas dan kualitas cengkih, produksi yang baik diperlukan suatu upaya, baik mulai pra tanam hingga pascapanen, salah satunya adalah dengan meningkatkan kualitas bibit. Penelitian tentang pembibitan cengkih untuk mendapatkan bibit yang berkualitas belum banyak dilakukan. Peningkatan produksi cengkih yang maksimal, baik di tingkat petani, perusahaan swasta maupun tingkat pemerintah dapat dilaksanakan dengan menggunakan bibit varietas cengkeh unggul. oleh karena itu penelitian tentang pembibitan cengkih perlu dilakukan. Untuk meningkatan pertumbuhan tanaman cengkih yang kurang terpelihara, diperlukan peremajaan agar tanaman cengkih dapat berproduksi kembali secara optimal. Salah satu komponen dalam upaya peremajaan adalah pemupukan. Pemupukan merupakan upaya yang bertujuan memberikan unsur hara yang kurang pada suatu lahan, baik unsur makro maupun unsur mikro serta menambah daya dukung tanah untuk menyediakan dan menstabilkan unsur hara agar tersedia untuk tanaman (Ruhnayat, 2007; Hardjowigeno, 1993). Menurut hasil penelitian Suherman (2006) terdapat pengaruh pupuk majemuk NPK dan fungi Mikoriza Arbuskula (FMA) terhadap jumlah daun dan tinggi tanaman cengkih Zanzibar. Berdasarkan hasil penelitian tersebut dapat diduga adanya pengaruh yang diberikan pupuk majemuk NPK dan kombinasi selain FMA, yaitu zat pengatur tumbuh (ZPT). Zat pengatur tumbuh didefinisikan sebagai senyawa organik bukan nutrisi yang aktif dalam jumlah kecil yang disintesis pada bagian tertentu dari tanaman dan pada umumnya diangkut ke bagian lain dari tanaman. Zat tersebut menimbulkan tanggap secara biokimia, fisiologis, dan morfologis (Wattimena, 1988). Dalam menunjang pertumbuhan pembibitan cengkih maka penggunaan auksin sebagai zat pengatur tumbuh dapat digunakan karena auksin dapat mempengaruhi perkembangan sel, menaikkan tekanan osmotik, meningkatkan sintesis protein, meningkatkan permeabilitas sel terhadap air dan melenturkan atau melunakkan dinding sel yang 
diikuti menurunnya tekanan dinding sel sehingga air dapat masuk ke dalam sel yang disertai dengan kenaikan volume sel (Hendaryono dan Wijayani, 1994).

Penelitian ini bertujuan mempelajari pengaruh pupuk majemuk NPK dan konsentrasi auksin terhadap pertumbuhan bibit tanaman cengkih serta untuk mendapatkan dosis pupuk majemuk NPK dan konsentrasi auksin yang optimum.

\section{BAHAN DAN METODE}

Penelitian dilakukan pada bulan November 2016 hingga Juni 2017 di Kebun Percobaan IPB Cikabayan Dramaga Bogor. dengan jenis tanah Latosol. Petak percobaan terdiri atas tiga petak yang berada di bawah tegakan tanaman karet sehingga petak percobaan ternaungi oleh pohon karet dengan persentase $50 \%-65 \%$. Pemindahan bibit dari polybag ukuran $12 \mathrm{~cm} \times 17 \mathrm{~cm}$ ke ukuran $25 \mathrm{~cm} \quad x \quad 30 \mathrm{~cm}$ dilakukan sebelum perlakuan.

Bahan yang digunakan adalah polybag hitam berukuran $25 \mathrm{~cm} \times 30 \mathrm{~cm}$, bibit cengkih varietas Zanzibar umur 2 bulan, pupuk majemuk NPK (15:15:15) dan auksin yang berasal dari sumber Hydrasil. Alat yang digunakan adalah cangkul, sprayer, sabit, timbangan digital, alat ukur : pita meter $1.5 \mathrm{~m}$, gelas ukur dan jangka sorong.

Rancangan percobaan yang digunakan adalah Rancangan Acak Kelompok (RAK) dengan pengacakan perlakuan secara faktorial. Faktor perlakuan pertama adalah dosis pupuk majemuk NPK yang terdiri atas 4 taraf, yaitu $5 \mathrm{~g}$ NPK sebagai kontrol (P0), 10 g NPK (P1), 15 g NPK (P2) dan 20 g NPK (P3) per bibit. Faktor perlakuan kedua yaitu pemberian Hydrasil yang mengandung 2.4-D, terdiri atas 4 taraf, yaitu: tanpa Hydrasil sebagai kontrol (Z0), $0.5 \mathrm{ml}$ Hydrasil (Z1), $1 \mathrm{ml}$ Hydrasil (Z2) dan $1.5 \mathrm{ml}$ Hydrasil (Z3).

Pelaksanaan kegiatan percobaan diawali dengan pembersihan gulma yang berada di sekitar dan di dalam polybag. Bibit dipindahkan dari polybag berukuran $12 \mathrm{~cm} \times 17 \mathrm{~cm}$ ke polybag berukuran $25 \mathrm{~cm} \times 30 \mathrm{~cm}$. Bibit yang telah dikelompokkan bedasarkan tinggi tanaman diberi pupuk NPK di daerah permukaan tanah dan menyemprotkan auksin dengan dosis dan konsentrasi sesuai perlakuan. Setelah itu, bibit dipindahkan ke pembibitan utama dengan naungan tegak tanaman karet. Bibit cengkih yang sudah dipindahkan ditata bedasarkan bagan acak perlakuan dengan jarak antar polybag dalam satuan percobaan $5 \mathrm{~cm}$, jarak parit ke parit percobaan sebesar $50 \mathrm{~cm}$, dan jarak antar ulangan $1 \mathrm{~m}$. Adapun total lahan yang dibutuhkan sebesar $812.3 \mathrm{~m}^{2}$.

Untuk menentukan volume semprot per bibit dilakukan kalibrasi dengan cara 1 liter air disemprotkan ke seluruh tajuk bibit hingga tetesan pertama pada daun bibit cengkih jatuh. Sisa air dalam alat semprot diukur. Volume air yang disemprotkan merupakan hasil pengurangan antara total volume air awal dengan volume air yang tersisa dalam alat semprot. Kalibrasi dilakukan 3 ulangan. Setelah mendapatkan ratarata volume air yang disemprotkan pada bibit tersebut, volume air yang disemprotkan dihitung berapa jumlah tekanan tuas yang dibutuhkan dari hasil rata rata volume semprot hingga habis untuk mendapatkan volume semprot per bibit. Pemberian pupuk NPK dan Hydrasil dilakukan sebanyak 3 kali dengan selang waktu 2 bulan selama percobaan.

Pemeliharaan tanaman meliputi penyiraman, penyiangan, pengendalian hama dan penyakit. Penyiraman dilakukan dua kali sehari, apabila tidak terjadi hujan. Penyiangan dilakukan apabila terdapat gulma dan dilakukan pengedalian dengan cara manual. Pengendalian hama dan penyakit dilakukan apabila ada gejala serangan. Parameter yang diamati pada percobaan ini adalah tinggi bibit, diameter bibit, jumlah daun, panjang akar, bobot tajuk, bobot akar dan rasio bobot akar dan tajuk.

\section{HASIL DAN PEMBAHASAN}

\section{Kondisi Umum Percobaan}

Kondisi Iklim pada awal bulan Oktober 2016 sampai Juni 2017 mengalami cuaca yang stabil. Bedasarkan data dari Badan Meteorologi, Klimatologi dan Geofisika (2017) curah hujan pada bulan November 2016 sampai Desember 2016 tergolong bulan kering dan Januari 2017 sampai Juli 2017 tergolong bulan basah, menurut klasifikasi iklim Schmidth-Ferguson (Tabel 1). Menurut Ruhnayat dan Dhalimi (1997) batas optimal curah hujan untuk pertumbuhan cengkih yang baik adalah $80 \mathrm{~mm}$ per bulan atau tergolong bulan lembab.

Jenis tanah pada tempat penelitian adalah Latosol dan tekstur tanah didominasi liat $75.76 \%$, kandungan pasir $4.99 \%$ dan debu $19.25 \%$. Reaksi tanah termasuk masam dengan $\mathrm{pH}(\mathrm{H} 2 \mathrm{O}) 4.7$, kandungan C-organik tinggi (3.38\%), kadar $\mathrm{N}$ sedang $(0.32 \%)$, kadar $\mathrm{P}$ tersedia sangat rendah (6.80 ppm) dan kadar K sedang (0.30 me $\left.100 \mathrm{~g}^{-1}\right)$. Hara makro sekunder seperti Ca tergolong rendah (3.30 me $100 \mathrm{~g}^{-1}$ ) dan Mg tergolong sedang (1.90 me $\left.100 \mathrm{~g}^{-1}\right)$. Kapasitas tukar kation tergolong 
sedang (19.47\%) dan kejenuhan basa sangat rendah (29.84\%) (Fauziah, 2013).

Pada 3 BSP (Bulan Setelah Perlakuan) sampai 5 BST banyak bibit cengkih mati disebabkan serangan cendawan Fusarium sp. Tanaman yang terserang mengalami gugur daun dan layu pada pucuk. Tanaman yang muda umumnya rentan terhadap infeksi penyakit. Pada jaringan yang masih terlalu muda biasanya patogen dapat dengan mudah masuk ke dalam jaringan tanaman dan mengganggu jaringan xylem (Basuki 1982). Pengendalian dilakukan dengan cara pemberian fungisida berbahan aktif mangkozep 20\% WP dengan dosis 2 g per liter. Penyemprotan dilakukan satu minggu sekali.

Penyebab lain kematian bibit cengkih diakibatkan oleh sunburn, pencucian hara dan lainnya akibat teknik pemindahan polybag. Sulistianingrum (2014) menyatakan tanaman cengkih mati sebanyak $17.5 \%$ dari populasi awal umumnya disebabkan oleh serangan rayap, sisanya serangan sunburn dan teknik penanaman bibit cengkih di lapangan.

Tabel 1. Kondisi cuaca selama percobaan

\begin{tabular}{lccc} 
Lokasi & \multicolumn{3}{l}{ Stasiun Klimatologi Dramaga Bogor } \\
Lintang & $: 06^{\circ} 31^{\prime} \mathrm{LS}$ & \\
Bujur & $: 106^{\circ} 44^{\prime} \mathrm{BT}$ & \\
Elevasi & $: 220 \mathrm{~m}$ di atas permukaan laut \\
Bulan & : November & 2016 sampai Juli 2017 \\
\hline Bulan & Suhu & Kelembaban & Curah Hujan \\
& $\left({ }^{\circ} \mathrm{C}\right)$ & Udara $(\%)$ & (mm/bulan) \\
\hline November & 25.99 & 87.17 & 13.47 \\
Desember & 26.04 & 82.61 & 6.48 \\
Januari & 25.88 & 83.71 & 130.4 \\
Febuari & 24.97 & 88.11 & 526.3 \\
Maret & 25.81 & 85.13 & 355.1 \\
April & 26.14 & 85.29 & 283.9 \\
Mei & 26.47 & 84.31 & 319.4 \\
Juni & 26.27 & 83.40 & 399.6 \\
Juli & 26.00 & 81.87 & 401.0 \\
Rata rata & 25.95 & 84.62 & 345.1 \\
\hline
\end{tabular}

Keterangan : BMKG (2017)

\section{Hasil}

\section{Respon Bibit Cengkih terhadap Pemberian Pupuk NPK}

Hasil sidik ragam menunjukkan bahwa dosis pupuk NPK cenderung berpengaruh nyata (Uji F pada $\alpha$ 0.1) terhadap nisbah BK tajuk / akar, tetapi tidak memberikan pengaruh nyata pada peubah lainnya (Tabel 3). Bibit cengkih yang dipupuk dengan dosis NPK $5 \mathrm{~g}$ per polybag secara fisik lebih tinggi dibandingkan dengan dosis pupuk NPK lainnya pada 0-5 BSP. Pertumbuhan bibit cengkih pada berbagai taraf dosis pupuk majemuk NPK dicantumkan pada Tabel 2.
Tabel 2. Pertumbuhan bibit cengkih pada berbagai dosis pupuk NPK pada 0-5 Bulan Setelah Pemupukan (BSP)

\begin{tabular}{|c|c|c|c|c|c|c|}
\hline \multirow{2}{*}{$\begin{array}{c}\text { Dosis Pupuk } \\
\text { NPK } \\
\text { (g/polybag) }\end{array}$} & \multicolumn{6}{|c|}{ Umur Bibit (BSP) } \\
\hline & 0 & 1 & 2 & 3 & 4 & 5 \\
\hline & \multicolumn{6}{|c|}{ Tinggi Tanaman $(\mathrm{cm})$} \\
\hline 5 & 17.3 & 19.2 & 20.9 & 22.4 & 24.3 & 26.0 \\
\hline 10 & 17.0 & 18.7 & 20.3 & 22.1 & 23.9 & 25.5 \\
\hline 15 & 16.9 & 18.9 & 20.5 & 22.4 & 24.1 & 25.9 \\
\hline \multirow[t]{2}{*}{20} & 16.8 & 18.9 & 20.6 & 22.0 & 23.7 & 25.4 \\
\hline & \multicolumn{6}{|c|}{ Diameter Batang $(\mathrm{mm})$. } \\
\hline 5 & 2.3 & 2.5 & 2.7 & 2.8 & 3.0 & 3.2 \\
\hline 10 & 2.3 & 2.5 & 2.7 & 2.8 & 3.0 & 3.2 \\
\hline 15 & 2.3 & 2.5 & 2.6 & 2.8 & 3.0 & 3.2 \\
\hline \multirow[t]{2}{*}{20} & 2.4 & 2.5 & 2.7 & 2.9 & 3.0 & 3.2 \\
\hline & \multicolumn{6}{|c|}{.. Jumlah Daun (helai) ........... } \\
\hline 5 & 3.5 & 6.0 & 8.5 & 11.0 & 13.5 & 15.9 \\
\hline 10 & 3.5 & 5.9 & 8.4 & 10.9 & 13.4 & 15.9 \\
\hline 15 & 3.5 & 6.0 & 8.6 & 11.1 & 13.5 & 16.0 \\
\hline 20 & 3.5 & 5.9 & 8.5 & 11.0 & 13.6 & 16.1 \\
\hline
\end{tabular}

Bobot basah dan kering akar, bobot basah dan kering tajuk serta nisbah BK tajuk/akar pada berbagai dosis pupuk majemuk NPK dicantumkan pada Tabel 3. Bobot basah akar dan bobot kering akar yang diberi dosis pupuk NPK $15 \mathrm{~g}$ per polybag secara fisik lebih besar dibandingkan pemberian dosis pupuk NPK lainnya (Tabel 3).

Tabel 3. Rata rata bobot basah, kering dan nisbah bobot terhadap pupuk

\begin{tabular}{cccccc}
\hline $\begin{array}{c}\text { Dosis } \\
\text { Pupuk NPK } \\
\text { g/polybag) }\end{array}$ & $\begin{array}{c}\text { Bobot } \\
\text { Basah } \\
\text { Tajuk }\end{array}$ & $\begin{array}{c}\text { Bobot } \\
\text { Kering } \\
\text { Tajuk }\end{array}$ & $\begin{array}{c}\text { Bobot } \\
\text { Basah } \\
\text { Akar }\end{array}$ & $\begin{array}{c}\text { Bobot } \\
\text { Kering } \\
\text { Akar }\end{array}$ & $\begin{array}{c}\text { Nisbah } \\
\text { BKTajuk } \\
\text { /BKAkar }\end{array}$ \\
\hline 5 & 3.6 & 1.9 & 1.9 & 1.1 & $1.6^{\mathrm{AB}}$ \\
10 & 2.6 & 1.9 & 1.7 & 1.1 & $1.7^{\mathrm{A}}$ \\
15 & 2.6 & 1.4 & 1.9 & 1.1 & $1.1^{\mathrm{B}}$ \\
20 & 3.8 & 2.1 & 1.9 & 1.1 & $1.8^{\mathrm{A}}$ \\
\hline Keterangan : Angka angka yang diikuti oleh huruf yang sama \\
dan pada kolom yang sama menunjukkan tidak \\
berbeda pada DMRT taraf $\alpha 0.1$
\end{tabular}

Hasil dari regresi menunjukkan bahwa dosis pupuk majemuk NPK sampai $20 \mathrm{~g}$ per bibit masih meningkatkan nisbah BK tajuk/akar. Persamaan regresi menunjukkan hasil yaitu $\mathrm{y}=$ $0.006 \mathrm{x}^{2}-0.15 \mathrm{x}+2.3$ dengan nilai $\mathrm{R}^{2}=0.3103$ (Gambar 1). Dosis pupuk majemuk NPK $5 \mathrm{~g}$ per bibit hingga $10 \mathrm{~g}$ per bibit mengalami penurunan, tetapi dari $15 \mathrm{~g}$ per bibit hingga $20 \mathrm{~g}$ per bibit mengalami peningkatan sehingga tidak didapatkan dosis optimum. Hal ini menunjukkan bahwa pada dosis pupuk majemuk NPK 5 g per bibit hingga $10 \mathrm{~g}$ per bibit cenderung berespon terhadap pertumbuhan akar, sedangkan pada dosis pupuk majemuk NPK $15 \mathrm{~g}$ per bibit hingga $20 \mathrm{~g}$ per bibit cederung berespon pada pertumbuhan tajuk. Adapun jatuhnya nisbah BK 
tajuk/akar pada pemberian dosis pupuk majemuk NPK 15 g per bibit disebabkan oleh pencucian hara yang terjadi selama penelitian. (Gambar 1).

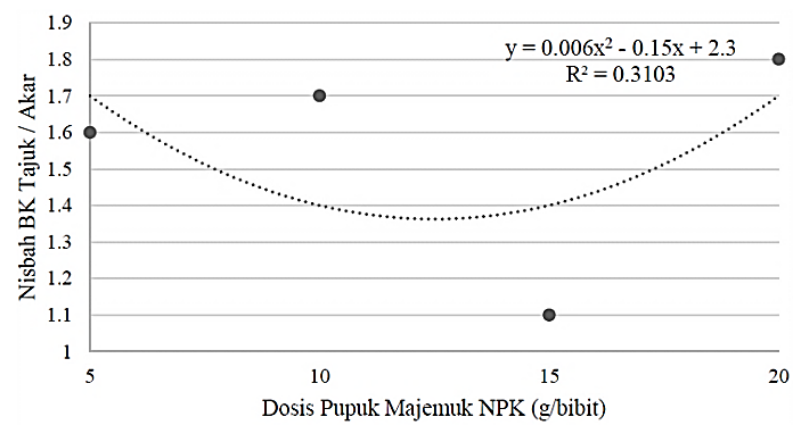

Gambar 1. Pola hubungan nisbah BK tajuk/akar dan dosis pupuk majemuk NPK

\section{Respon Bibit Cengkih terhadap Pemberian Auksin}

Hasil sidik ragam menunjukkan bahwa konsentrasi auksin memberikan pengaruh nyata terhadap tinggi tanaman pada 0-1 BST dan cenderung berpengaruh nyata (Uji F pada $\alpha 0.1$ ) terhadap tinggi bibit pada 4 dan 5 BSP, tetapi tidak memberikan pengaruh nyata terhadap peubah lainnya. Tinggi bibit pada umur 1 BST yang diberi auksin dengan konsentrasi $0.5-1.5$ $\mathrm{ml}$ per liter lebih tinggi dibandingkan kontrol tetapi ketiga konsentrasi auksin tersebut tidak berbeda. Tinggi bibit pada umur $4-5$ BST yang diberi auksin dengan konsentrasi 0.5 dan $2.5 \mathrm{ml}$ per liter air cenderung lebih tinggi dibandingkan kontrol tetapi kedua konsentrasi auksin tersebut tidak berbeda (Tabel 4).

Tabel 4. Pertumbuhan bibit cengkih pada berbagai konsentrasi auksin pada 0-5 Bulan Setelah Pemupukan (BSP)

\begin{tabular}{|c|c|c|c|c|c|c|}
\hline \multirow{2}{*}{$\begin{array}{l}\text { Konsentrasi } \\
\text { Auksin } 2.4 \mathrm{D} \\
\text { (ml/liter air) }\end{array}$} & \multicolumn{6}{|c|}{ Umur Bibit (BSP) } \\
\hline & 0 & 1 & 2 & 3 & 4 & 5 \\
\hline & \multicolumn{6}{|c|}{.......... Tinggi Tanaman $(\mathrm{cm})$........... } \\
\hline 0 & 16.4 & $18.3^{\mathrm{b}}$ & 20.1 & 21.7 & $23.4^{\mathrm{B}}$ & $25.1^{\mathrm{B}}$ \\
\hline 0.5 & 16.9 & $19.0^{\mathrm{a}}$ & 20.8 & 22.6 & $24.4^{\mathrm{A}}$ & $26.0^{\mathrm{A}}$ \\
\hline 1 & 16.8 & $19.0^{\mathrm{a}}$ & 20.7 & 22.2 & $23.9^{\mathrm{AB}}$ & $25.5^{\mathrm{AB}}$ \\
\hline \multirow[t]{2}{*}{1.5} & 17.6 & $19.3^{\mathrm{a}}$ & 20.8 & 22.5 & $24.3^{\mathrm{A}}$ & $26.1^{\mathrm{A}}$ \\
\hline & \multicolumn{6}{|c|}{ Diameter Batang $(\mathrm{mm})$............ } \\
\hline 0 & 2.3 & 2.5 & 2.7 & 2.9 & 3.0 & 3.2 \\
\hline 0.5 & 2.3 & 2.5 & 2.7 & 2.8 & 3.0 & 3.2 \\
\hline 1 & 2.4 & 2.5 & 2.7 & 2.9 & 3.0 & 3.2 \\
\hline \multirow[t]{2}{*}{1.5} & 2.3 & 2.5 & 2.6 & 2.8 & 3.0 & 3.2 \\
\hline & \multicolumn{6}{|c|}{.......... Jumlah Daun (helai) ........... } \\
\hline 0 & 3.5 & 6.0 & 8.5 & 11.1 & 13.6 & 16.2 \\
\hline 0.5 & 3.5 & 6.0 & 8.5 & 11.0 & 13.5 & 16.0 \\
\hline 1 & 3.5 & 6.0 & 8.4 & 10.9 & 13.4 & 15.8 \\
\hline 1.5 & 3.5 & 6.0 & 8.5 & 11.0 & 11.0 & 15.9 \\
\hline
\end{tabular}

Keterangan: Angka angka yang diikuti oleh huruf yang sama dan pada kolom yang sama menunjukkan tidak berbeda pada DMRT taraf $\alpha 0.05$ (huruf kecil) dan taraf $\alpha 0.1$ (huruf besar)
Hasil dari regresi menunjukkan bahwa konsentrasi auksin paling optimum pada tinggi tanaman sebesar $1.58 \mathrm{ml} /$ liter air, konsentrasi optimum didapat bedasarkan dari persamaan $\mathrm{y}=$ $0.3 \mathrm{x}^{2}+0.95 \mathrm{x}+25.225$ dengan $\mathrm{R}^{2}=0.5174$ (Gambar 2).

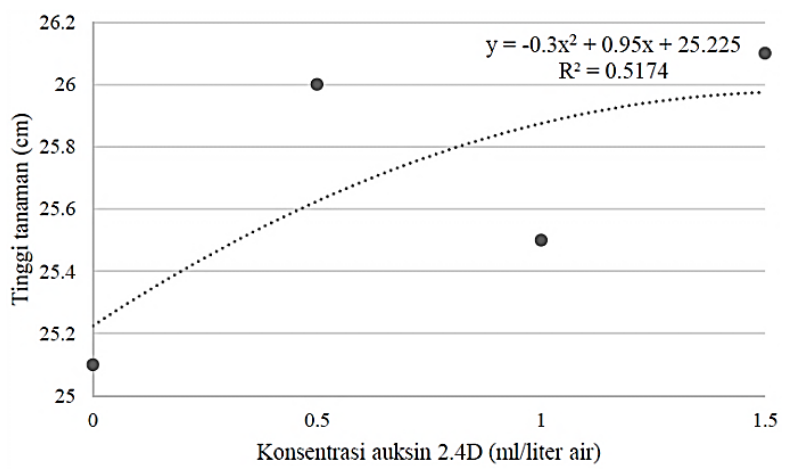

Gambar 2. Pola hubungan tinggi bibit cengkih dan berbagai konsentrasi auksin

Hasil sidik ragam menunjukkan bahwa konsentrasi auksin tidak memberikan pengaruh nyata terhadap bobot basah, bobot kering dan nisbah bobot kering tajuk/akar. Bobot basah dan kering akar, bobot basah dan kering tajuk serta nisbah BK tajuk/akar pada berbagai konsentrasi auksin terdapat pada Tabel 5 .

Tabel 5. Rata rata bobot basah, kering dan rasio bobot kering tajuk/bobot kering akar terhadap auksin

\begin{tabular}{cccccc}
\hline $\begin{array}{c}\text { Konsentrasi } \\
\begin{array}{c}\text { Auksin } \\
2.4 \mathrm{D} \\
(\mathrm{ml} / \text { liter air) }\end{array}\end{array}$ & $\begin{array}{c}\text { Bobot } \\
\text { Basah } \\
\text { Tajuk }\end{array}$ & $\begin{array}{c}\text { Bobot } \\
\text { Kering } \\
\text { Tajuk }\end{array}$ & $\begin{array}{c}\text { Bobot } \\
\text { Basah } \\
\text { Akar }\end{array}$ & $\begin{array}{c}\text { Bobot } \\
\text { Kering } \\
\text { Akar }\end{array}$ & $\begin{array}{c}\text { Nisbah } \\
\text { BKTajuk } \\
\text { /BKAkar }\end{array}$ \\
\hline 0 & 2.8 & 1.9 & 1.9 & 1.2 & 1.4 \\
0.5 & 3.2 & 1.4 & 1.4 & 0.8 & 1.6 \\
1 & 2.9 & 1.6 & 1.7 & 1.0 & 1.4 \\
1.5 & 3.7 & 2.4 & 2.3 & 1.4 & 1.7 \\
\hline
\end{tabular}

\section{Respon Bibit Cengkih terhadap Interaksi pupuk NPK dan Auksin}

Hasil sidik ragam menunjukkan bahwa terdapat pengaruh nyata interaksi pupuk majemuk NPK dan auksin 2.4-D terhadap panjang akar. Panjang akar pada kombinasi $5 \mathrm{~g}$ pupuk NPK per bibit dan pemberian auksin $0.5 \mathrm{ml}$ per liter air secara fisik memberikan hasil paling optimum. Pemberian hydrasil $0 \mathrm{ml}$ per liter air memberikan respon terbaik pada dosis pupuk NPK $10 \mathrm{~g}$ per bibit, pemberian hydrasil $0.5 \mathrm{ml}$ per liter air memberikan respon terbaik pada dosis pupuk NPK 5 g per bibit, pemberian hydrasil $1 \mathrm{ml}$ per liter air memberikan respon optimal pada semua pemberian dosis pupuk NPK dan pemberian hydrasil dengan konsentrasi 1.5 memberikan respon yang optimal pada dosis pupuk NPK g per bibit dan $20 \mathrm{~g}$ per bibit. (Tabel 6). 
Tabel 6. Rata rata panjang akar terhadap pemberian kombinasi Pupuk NPK dan Auksin 2.4-D

\begin{tabular}{ccccc}
\hline Dosis & \multicolumn{5}{c}{ Konsentrasi Hydrasil (ml/liter air) } \\
\cline { 2 - 5 } $\begin{array}{c}\text { Pupuk } \\
\text { NPK } \\
\text { (g/polybag) }\end{array}$ & 0 & 0.5 & 1 & 1.5 \\
\hline \multicolumn{5}{c}{$\ldots \ldots \ldots$. Panjang Akar (cm)......... } \\
5 & $15.7^{\mathrm{b}}$ & $25.3^{\mathrm{a}}$ & $20.8^{\mathrm{a}}$ & $23.6^{\mathrm{a}}$ \\
10 & $22.3^{\mathrm{a}}$ & $18.3^{\mathrm{b}}$ & $23.2^{\mathrm{a}}$ & $19.5^{\mathrm{ab}}$ \\
15 & $18.9^{\mathrm{ab}}$ & $20.9^{\mathrm{ab}}$ & $23.7^{\mathrm{a}}$ & $16.5^{\mathrm{ab}}$ \\
20 & $18.9^{\mathrm{ab}}$ & $21.5^{\mathrm{ab}}$ & $18.1^{\mathrm{a}}$ & $23.1^{\mathrm{a}}$ \\
\hline
\end{tabular}

Keterangan : angka-angka yang diikuti huruf sama tidak berbeda nyata pada uji DMRT taraf $\alpha 0.05$

Bobot basah tajuk pada kombinasi pemberian auksin $1.5 \mathrm{ml}$ per liter air dan $5 \mathrm{~g}$ pupuk NPK per bibit secara fisik memberikan hasil paling optimum. Pemberian tanpa auksin memberikan respon terbaik pada dosis pupuk NPK 5 g per bibit, pemberian auksin $0.5 \mathrm{ml}$ per liter air memberikan respon terbaik pada dosis pupuk NPK $5 \mathrm{~g}$ per bibit, pemberian auksin $1 \mathrm{ml}$ per liter air memberikan respon terbaik pada dosis pupuk NPK $5 \mathrm{~g}$ per bibit dan pemberian auksin dengan konsentrasi $1.5 \mathrm{ml}$ per liter air memberikan respon yang optimal pada dosis pupuk NPK g per bibit dan $5 \mathrm{~g}$ per bibit (Tabel 7).

Tabel 7. Rata rata bobot basah tajuk terhadap pemberian kombinasi Pupuk NPK dan Auksin 2.4-D

\begin{tabular}{ccccc}
\hline Dosis Pupuk & \multicolumn{5}{c}{ Konsentrasi Hydrasil (ml/liter air) } \\
\cline { 2 - 5 } $\begin{array}{c}\text { NPK } \\
\text { (g/polybag) }\end{array}$ & 0 & 0.5 & 1 & 1.5 \\
\hline \multicolumn{5}{c}{$\ldots \ldots \ldots \ldots$. Bobot (g/bibit)......... } \\
5 & $3.24^{\mathrm{A}}$ & $1.03^{\mathrm{B}}$ & $4.64^{\mathrm{A}}$ & $5.50^{\mathrm{A}}$ \\
10 & $3.19^{\mathrm{A}}$ & $3.40^{\mathrm{AB}}$ & $1.30^{\mathrm{B}}$ & $2.74^{\mathrm{B}}$ \\
15 & $2.60^{\mathrm{A}}$ & $2.50^{\mathrm{B}}$ & $2.62^{\mathrm{AB}}$ & $2.60^{\mathrm{B}}$ \\
20 & $2.27^{\mathrm{A}}$ & $5.70^{\mathrm{A}}$ & $3.20^{\mathrm{AB}}$ & $4.17^{\mathrm{AB}}$ \\
\hline
\end{tabular}

Keterangan : angka-angka yang diikuti huruf sama tidak berbeda nyata pada uji DMRT taraf $\alpha 0.1$

Pembahasan

\section{Pengaruh Pupuk NPK terhadap Pertumbuhan Bibit Cengkih}

Pertumbuhan tanaman sangat dipengaruhi oleh ketersediaan unsur hara dalam tanah. Defisiensi unsur hara dapat menyebabkan pertumbuhan tanaman terganggu. Jika tanah menghasilkan pertumbuhan tanaman yang baik, tanah tersebut kemungkinan mempunyai persediaan yang cukup dari semua unsur-unsur yang penting (esensial) untuk tanaman atau unsurunsur hara. Tidak hanya menyediakan unsur-unsur hara dalam bentuk- bentuk yang dikehendaki tanaman, tetapi juga menyediakannya dalam keadaan seimbang sesuai dengan jumlah yang dibutuhkan tanaman. Jika setiap unsur-unsur ini kurang satu atau terdapat dalam imbangan yang tidak cukup, pertumbuhan secara normal tidak akan terjadi (Foth et al., 1988).

Nitrogen, fosfor dan kalium adalah tiga unsur makro yang dibutuhkan oleh tanaman. Pupuk NPK merupakan pupuk majemuk yang mengandung tiga unsur sekaligus yang merupakan gabungan dari pupuk tunggal $\mathrm{N}, \mathrm{P}$ dan K (Lingga, 1998). Peran utama nitrogen bagi tanaman ialah untuk merangsang pertumbuhan tanaman secara keseluruhan, khususnya batang, cabang, dan daun. Kecuali itu nitrogen juga berperan penting dalam hal pembentukan hijau daun yang berguna sekali dalam proses fotosintesis. Fungsi lain ialah membentuk protein, lemak dan berbagai persenyawaan lainnya (Lingga, 1998). Tanaman yang kekurangan unsur hara nitrogen akan berwarna hijau, daun bawah menguning, mengering sampai berwarna coklat muda dan terlihat pula batangnya pendek dan lemah. Unsur fosfor bagi tanaman berguna untuk merangsang pertumbuhan akar dan tanaman muda. Fosfor juga sebagai bahan mentah untuk pembentukan sejumlah protein tertentu. Membantu asimilasi dan pernafasan sekaligus mempercepat pembungaan, pemasakan biji, dan buah (Lingga, 1998). Jika tanaman kekurangan fosfor maka tanaman akan berwarna hijau tua, sering memperlihatkan warna merah atau ungu, daun bawah kadang-kadang berwarna kuning mengering sampai berwarna cokelat kehijauan atau hitam dan batang pendek kecil-kecil. Faedah utama kalium membantu pembentukan protein dan karbohidrat. Kalium juga berperan memperkuat tubuh tanaman agar daun, bunga dan buah tidak mudah gugur, serta sebagai sumber kekuatan bagi tanaman menghadapi kekeringan dan penyakit (Lingga, 1998). Oleh karena itu, pemupukan yang seimbang penting untuk membuat pertumbuhan bibit cengkih menjadi optimum, tetapi pada pelaksanaanya terjadi gangguan yang menyebabkan asupan bibit menjadi tidak optimal.

Tidak berpengaruhnya pemberian pupuk NPK bedasarkan sidik ragam terjadi karena pencucian hara pada polybag oleh curah hujan yang tinggi selama percobaan berlangsung. Hal ini disebabkan unsur utama pupuk NPK seperti nitrogen dan kalium yang bersifat mudah tercuci. Leiwakabessy dan Sutandi (2004) menyatakan bahwa sifat nitrogen mudah sekali tercuci air.

Pemberian pupuk NPK dengan dosis $5 \mathrm{~g}$ per bibit meningkatkan sekitar $6 \%$ tinggi bibit setiap 4 minggu. Hal ini juga terjadi pada pemberian pupuk NPK dengan dosis $10 \mathrm{~g}$ per bibit dan $15 \mathrm{~g}$ per bibit, sedangkan pemberian 20 g per bibit memberikan 5\% tinggi bibit setiap 4 minggu. 


\section{Pengaruh Auksin 2.4-D terhadap Pertumbuhan Bibit Cengkih}

Auksin 2.4-D dapat memberikan pengaruh kepada pertumbuhan bibit cengkih apabila dengan konsentrasi yang sesuai. Menurut Agustini (1989) pemberian auksin dengan konsentrasi tertentu dapat meningkatkan pertumbuhan tanaman jagung. Pembelahan sel yang terus menurus pada suatu tanaman dapat mengakibatkan peningkatan pada tinggi tanaman tersebut.

Pada penelitian, pemberian hydrasil pada berbagai konsentrasi berpengaruh nyata pada tinggi bibit cemgkih pada 2-3 BSP. Menurut Dwiwarni (1989) konsentrasi auksin $2.5 \mathrm{ml}$ per liter air dapat meningkatkan pertumbuhan bibit cengkih sebesar 5\% daripada kontrol. Pemberian Auksin 2.4-D pada dosis $1.5 \mathrm{ml}$ per liter air meningkatkan $7 \%$ tinggi tanaman cengkih dibanding kontrol pada 8-10 MST, sedangkan pada 12 MST meningkatkan $15 \%$ dibanding kontrol.

Auksin memiliki fungsi mempercepat pertumbuhan akar, mendorong perpanjangan dan pengembangan sel, fototropisme, dan mempercepat perkecambahan, serta dominasi apical. Auksin dapat berpengaruh terhadap perkembangan kuncup samping (Gardner et al., 2008). Pada konsentrasi tertentu 2.4-D dapat berperan sebagai herbisida, tetapi dengan konsentrasi sesuai anjuran dapat menjadi zat pengatur tumbuh tanaman (Agustini, 1989).

Pemberian konsentrasi Auksin 2.4-D pada $1.5 \mathrm{ml}$ per liter air merupakan konsentrasi optimum. Sifat dari Hydrasil (berbahan aktif 2.4D) pada tanaman dengan konsentrasi dan waktu pemberian yang tepat akan meningkatkan daya penetrasi Hydrasil ke dalam daun melalui stomata. Pemberian Hydrasil dengan konsentrasi di atas 2 $\mathrm{ml}$ per liter air akan memperlambat rata-rata tinggi tanaman cengkih (Kiptantiyawati 2016). Pemberian Hydrasil dua kali pada 21 HST dan 40 HST pada tanaman jagung dengan konsentrasi $0.75 \mathrm{ml}$ per liter air dapat menaikkan hasil pipilan kering sebesar $13 \%$ dan pemberian Hydrasil dengan konsentrasi $1.5 \mathrm{ml}$ per liter air menaikkan hasil pipilan kering sebesar 15\% (Bangun et al., 1983). Hal ini membuktikan bahwa konsentrasi Hydrasil di atas $2.0 \mathrm{ml}$ per liter dapat memperlambat pertumbuhan tinggi rata-rata sebesar $15 \%$. Panjang akar pada kombinasi $5 \mathrm{gr}$ pupuk NPK per Polybag dan pemberian auksin $0.5 \mathrm{ml}$ per liter air secara fisik memberikan hasil paling optimum dan memberikan interaksi.

\section{Respon Bibit Cengkeh terhadap interaksi Pupuk NPK dan Auksin}

Kefektifan aplikasi suatu jenis auksin juga dipengaruhi oleh kondisi hara tanaman (Leopold,
1963). Pada panjang akar, pemberian hydrasil tanpa auksin memberikan respon terbaik pada dosis pupuk NPK $10 \mathrm{~g}$ per bibit, pemberian hydrasil $0.5 \mathrm{ml}$ per liter air memberikan respon terbaik pada dosis pupuk NPK 5 g per bibit, pemberian hydrasil $1 \mathrm{ml}$ per liter air memberikan respon optimal pada semua pemberian dosis pupuk NPK dan pemberian hydrasil dengan konsentrasi 1.5 memberikan respon yang optimal pada dosis pupuk NPK g per bibit dan $20 \mathrm{~g}$ per bibit.

Pada bobot basah tajuk, pemberian tanpa auksin memberikan respon terbaik pada dosis pupuk NPK $5 \mathrm{~g}$ per bibit, pemberian auksin $0.5 \mathrm{ml}$ per liter air memberikan respon terbaik pada dosis pupuk NPK $10 \mathrm{~g}$ per bibit, pemberian auksin $1 \mathrm{ml}$ per liter air memberikan respon terbaik pada dosis pupuk NPK $5 \mathrm{~g}$ per bibit dan pemberian auksin dengan konsentrasi $1.5 \mathrm{ml}$ per liter air memberikan respon yang optimal pada dosis pupuk NPK g per bibit dan $5 \mathrm{~g}$ per bibit.

\section{KESIMPULAN}

Pemberian pupuk majemuk NPK cenderung berpengaruh nyata terhadap rasio bobot akar, tetapi tidak memberikan pengaruh nyata pada peubah lainnya. Konsentrasi auksin memberikan pengaruh nyata terhadap tinggi tanaman pada 0-1 BST dan cenderung berpengaruh nyata terhadap tinggi bibit pada 4 dan 5 BSP, tetapi tidak memberikan pengaruh nyata terhadap peubah lainnya. Terdapat pengaruh nyata interaksi pupuk majemuk NPK dan auksin terhadap panjang akar dan cenderung berpengaruh nyata terhadap bobot basah tajuk. Tidak ditemukannya dosis optimum pada pupuk majemuk NPK untuk pertumbuhan bibit cengkih, tetapi terdapat konsentrasi optimum dalam pemberian auksin $2.4 \mathrm{D}$ yaitu sebesar $1.58 \mathrm{ml}$ per liter air dalam pertumuhan tinggi bibit cengkih.

Faktor curah hujan dan serangan Fusarium $s p$. Menjadi salah satu faktor besar dalam pengaruh terhambatnya pertumbuhan bibit selama penelitian. Faktor sunburn sekiranya tidak terlalu memberikan dampak besar tetapi tetap menjadi faktor yang harus diperhatikan dalam pertumbuhan bibit selama penelitian berlangsung.

\section{DAFTAR PUSTAKA}

Agustini, S. 1989. Pemberian berbagai taraf konsentrasi hydrasil pada dua tipe jagung (Zae mays L.). [Skripsi]. Institut Pertanian Bogor. Bogor. 
Bangun, P., H. Pane, Partasasmita. 1983. Pengaruh perangsang tumbuhan hydrasil pada tanaman jagung dan kedelai. Kelti Agronomi. Balai Penelitian Tanaman Pangan Bogor 1-10.

Basuki, 1982. Penyakit dan gangguan pada tanaman karet. Pusat Penelitian Perkebunan Tanjung Morawa. Tanjung Morawa.

[BMKG] Badan Meteorlogi Klimatologi dan Geofisika. 2017. Data Iklim Stasiun Dramaga. BMKG. Bogor.

Dwiwarni, I. 1989. Pengaruh pemberian zat pengatur tumbuh terhadap pertumbuhan bibit cengkih. Pembr. Litri. 14(4): 126-129.

[Ditjenbun] Direktorat Jendral Perkebunan. 2016. Statistik Perkebunan Indonesia 2015 - 2017 Cengkih. Departemen Pertanian. Jakarta.

[Ditjenbun] Direktorat Jenderal Perkebunan. 2013. Pedoman Teknis Pengembangan Tanaman Cengkih Tahun 2014. Kementrian Pertanian. Jakarta.

Disbun Jabar. 2014. Informasi Komoditas Cengkih. http://disbun.jabarprov.go.id/index.php/sub Menu/640] (2013[2014 3 17]): Bandung.

Fauziah, R.R. 2013. Optimasi dosis pupuk majemuk NPK dan kalsium pada bibit kelapa sawit (Elaeis guineensis Jacq.) di pembibitan utama. [Tesis]. Institut Pertanian Bogor. Bogor.

Foth, H.D., E.D. Purbayanti, D.R. Lukiwati, R. Trimulatsih. 1988. Dasar-Dasar Ilmu Tanah. S.A.B. Hudoyo, editor. Gadjah Mada University Press. Yogyakarta.

Gardner, F.P., R.B. Pearce, Mitchell R.L. 2008. Fisiologi Tanaman Budidaya. S. Susilo, penerjemah; Subiyanto, editor. UI Press. Jakarta. Terjemahan dari: Physiology of Crop Plants. The Lowa State, University Press.

Hardjowigeno, S. 1993. Ilmu Tanah. Pustaka Utama. Jakarta

Hendaryono, D.P.S., A. Wijayani 1994. Teknik Kultur Jaringan Perbanyakan dan Petunjuk Perbanyakan Tanaman secara Vegetatif. Kasinus. Yogyakarta.
Indrawanto, C., Y. Ferry. 2007. Peningkatan pendapatan petani cengkih melalui peningkatan kinerja indusri cengkih nasional. Prosiding Seminar Nasional Rempah. Pusat Penelitian dan Pengembangan Perkebunan. Hal. 352-361.

Kiptantiyawati, N. 2016. Pertumbuhan tanaman cengkih (Syzygium aromaticum (L.) Merr \& Perr) belum menghasilkan pada berbagai dosis pupuk organik dan konsentrasi hydrasil [skripsi]. Institut Pertanian Bogor. Bogor.

Leopold, A.C. 1963. Auxin and Plant Growth. University of California Press. Ames Iowa, USA. 194p.

Lingga, P. 1998. Petunjuk Penggunaan Pupuk. Penebar Swadaya. Jakarta.

Leiwakabessy, F.M., A. Sutandi. 2004. Diktat Kuliah Pupuk dan Pemupukan. Departemen Tanah, Fakultas Pertanian, Institut Pertanian Bogor. Bogor.

Ruhnayat, A. 2007. Aplikasi model pemupukan berimbang pada tanaman cengkih (Syzigium aromaticum). Bul Littro. 18(2):149-158.

Ruhnayat, A., A. Dhalimi. 1997. Fluktuasi hasil cengkih. Balittro. Monograf-2 : 50-54.

Rumagit, G.A.J. 2007. Kajian Ekonomi Keterkaitan Antara Perembangan Industri Rokok Kretek Nasional. IPB Press. Bogor.

Suherman, C. 2006. Pertumbuhan Bibit Cengkih (Euginia aromatica $\mathrm{O}$. K) Kultivar Zanzibar yang diberi Fungi Mikoriza. UNPAD Press. Siap terbit.

Sulistianingrum, R. 2014. Pertumbuhan tanaman cengkih (Syzygium aromaticum (L.) Merr Perr) belum menghasilkan pada berbagai dosis pupuk organik dan intensitas naungan. [Skripsi]. Institut Pertanian Bogor. Bogor.

Wahyuno, D., E. Martini. 2015. Pedoman Budi Daya Cengkeh di Kebun Campur. World Agroforestry Centre (ICRAF). Bogor.

Wattimena, G.A. 1988. Zat Pengatur Tumbuh Tanaman. PAU IPB. Bogor. 